\title{
Influence of Education and Work Experience on Work Motivation and Job Performance at Branch Office of BANK J Trust Bank Surabaya
}

\author{
Ani Wulandari \\ Narotama University \\ Wulandari88@gmail.com
}

\begin{abstract}
The purpose of this study is to analyze the Effect of Education and Work Experience on Work Motivation and Job Performance in J TRUST BANK Branch Office Surabaya. The result showed that education has positive and significant effect on work motivation, seen from $t$ count $(3,866)>$ value of $t$ table $(1,682)$, it can be said that there is a partially significant influence from educational variable to work motivation in J TRUST BANK branch in Surabaya amounting to $46,1 \%$. Work experience has a positive and significant effect to work motivation, seen from $t$ count $(3,150)>$ from $t$ table $(1,682)$, it can be said that there is a partially significant influence from work experience variable to work motivation in J TRUST BANK branch in Surabaya which equal to $37,5 \%$. Education has a positive and significant effect to work performance, seen from $t$ count $(2,764)>$ from $t$ table $(1,682)$, it can be concluded that there is a partially significant influence from educational variable to achievement of work atJ TRUST BANK Branch in Surabaya at 35.7\%.
\end{abstract}

Keywords: Education, Work Experience, Work Motivation and Job Performance.

\section{INTRODUCTION}

$J$ Trust Bank is one of a banking business entity engaged in Indonesia with many branches, one of the branch office is located in Surabaya. Surabaya Branch Office consists of four units of work underlying also continue to strive to improve the performance of its work unit, one of them is by improving the achievement of the company that could only be achieved if all individuals within the company are able to show their best performance through achievements. In addition, J Trust Bank must also be able to minimize the possibility of labor irregularities that may occur inside the company, because this will be related to service performance that is expected to continue escalating and providing satisfactory services that will make customers entrust more liquidity managed by $\mathrm{J}$ Trust Bank. To achieve that, of course, there are

Influence of Education and Work Experience on Work Motivation and Job Performance at Branch Office of BANK J Trust Bank Surabaya 
many things that need to be considered related to work performance by observing factors that may be the cause, ranging from educational background, work experience, and work motivation of the workforce(Barid, Wajdi, Ummah, \& Etikasari, 2017)

Education is all learning experiences that take place in all environments and throughout life and education can be interpreted as teaching held in schools as formal education institutions, Mudyaarjo (2006: 3). Based on the results of the study (Rina Rahayu, 2015) Education is equal to 0.265 with the level of significance amounting to $0.002<0.05$. This means that there is a partial influence of the Education variable to Financial Deviation Behavior of PT Meratus Line. Work Experience is as a measure of the length of time or period of work a person has taken in understanding the tasks of a job and has done well (Foster, 2001: 40). According to Wibowo (2010: 379), motivation is the impetus to a series of processes of human behavior on the achievement of goals. While the factors contained in the motivation includes the elements of generating, directing, maintaining, showing intensity, continuous and existence of purpose. Based on research (Kurniawan and Alimudin, 2015) work motivation, and discipline partially significant to the performance of Employees of PT. SALT (Persero), validated the truth. Among motivation, work experience and work discipline, the most influential variable to the employee productivity of PT Global Teleshop Surabaya is motivation, this is indicated by the value of partial determination coefficient of 0.384 or $38.4 \%$ larger than the other variables. (Ningtias Prawita, 2015).

According to Djauzak (2004: 57), the factors that can affect one's work experience is time, frequency, type of task, application, and results. Experience will help the company to improve service quality and create customer loyalty. This is similar to the results of research by (Alimudin and Yoga, 2015) that stated a combination for product innovation and the market is a must to do to build and improve customer loyalty. 
In addition, there are also some things to determine whether or not an employee is experienced in work, which can also be an indicator of work experience according to (Foster, 2001: 43), namely:

\section{a. Duration of Time or Work Period}

The length of time a person has gone through until he or she can understand the tasks of a job and able to handle the job well.

b. Level of Knowledge and Skills

C. Mastery of Work and Equipment

Mastery level of a person in the implementation of engineering aspects of equipment and work techniques

$\mathrm{H} 1$ : There is an effect of education on work motivation in J Trust Bank Surabaya Branch

$\mathrm{H} 2$ : There is influence of work experience to work motivation at J Trust Bank Surabaya Branch

H3: There is an influence of educational influence on job performance in $\mathrm{J}$ Trust Bank Surabaya Branch

$\mathrm{H} 4$ : There is an effect of work experience on job performance at J Trust Bank Surabaya Branch

H5: There is an effect of education on job performance through work motivation at $J$ Trust Bank Surabaya Branch

H6: There is an effect of work experience on job performance through work motivation at J Trust Bank Surabaya Branch

H7: There is an influence of work motivation on job performance in J Trust Bank Surabaya Branch

\section{METHOD}

In this research, the research approach used is quantitative method. The quantitative approach is one of the scientific inquiry based on logical positivism that operates with strict rules of logic, truth, laws and prediction (Watson, in Danim 2002). 
Population in this research is employees of operational section in J Trust Bank Surabaya Branch as much 45 people. The data collection is done by census. To analyze the data, path analysis technique is utilized. Path analysis is an extension of multiple regression analysis, or the use of regression analysis to estimate the relation of casuality between predefined variables based on theory (Ghozali, 2005: 160). The path diagrams provide explicitly the relationship of inter-variable quality based on the theory. The arrows show the relationship between variables. The model moves from left to right with the priority implications of variable causal relationships close to the left. Each path value (p) represents the path and path coefficients. In this study the independent variables are Education (X1), Work Experience (X2), and Work Motivation (Z), while the dependent variable is Work Achievement (Y). So the research flow is described as follows (Ghozali, 2005: 160).

The equations in this model consist of two stages:

$Z=b 1 X 1+b 2 X 2+e 1(1)$

Information :

Z: Work Achievement

$\mathrm{X} 1$ : Education

X2: Work Experience

X3: Work Motivation

b1: Education coefficient

b2: Work Experience coefficient

e1: Residual

$\mathrm{Y}=\mathrm{b} 1 \mathrm{X} 1+\mathrm{b} 2 \mathrm{X} 2+\mathrm{bzZ}+\mathrm{e} 2(2)$

Information :

Y: Work Achievement

$\mathrm{X} 1$ : Education

X2: Work Experience

Z: Work Motivation

b1: Education coefficient 
b2: Work Experience coefficient

bz: Work Motivation coefficient

e1: Residual

\section{RESULT ANALYSIS AND DISCUSSION}

1. Education Influence towards Work Motivation

The influence of education on work motivation for $t$ count $(3,866)>$ of $t$ table $(1,682)$, therefore it can be said that there is partially significant influence of education variable on work motivation in J Trust Bank Surabaya Branch, and regression coefficient value equal to 0,461 . The positive value is inline with worker motivation in J Trust Bank Surabaya Branch. From this, it is able to be concluded that the education of each worker is able to boost the increase of their work motivation in work.

2. Work Experience Influence towards Work Motivation

The influence of work experience on work motivation for t count $(3,150)>$ from t table $(1,682)$, thus it seen that there is partially significant influence from work experience variable to work motivation in J Trust Bank Surabaya Branch and regression coefficient value equal to 0.375 . The positive value is in line with worker motivation in J Trust Bank Surabaya Branch. It is clear that work experience of each worker is able to motivate them in working to show maturity in their job.

3. 3. Education Influence on Job Performance

The effect of education on job performance for $t$ count $(2,764)>$ of $t$ table $(1,682)$, therefore it is concluded that there is a partially significant influence of education variable on job performance in $\mathrm{J}$ Trust Bank Surabaya Branch. and regression coefficient value is 0,357 . The positive value is inline towards worker achievement in $\mathrm{J}$ Trust Bank Surabaya Branch. As for that, the education of the worker could determine their work achievement later on. 
4. Work Experience Influence on Job Performance

The effect of work experience on job performance for $t$ count (3.013) > from $t$ table $(1,682)$, thus there is a partially significant influence from work experience variable on job performance in J Trust Bank Surabaya Branch, and regression coefficient value of 0.389 . The positive value is inline with worker achievement in J Trust Bank Surabaya Branch. It can be stated that the experience of each worker can determine the work performance they will achieve later.

5. Education Influence on Job Performance through Work Motivation

The effect of education on work achievement through work motivation for $t$ count of education $(2,764)$ and $t$ count of motivation $(6,312)>$ from $t$ table $(1,682)$, therefore there is a partially significant influence from education variable to work performance through work motivation in J Trust Bank Surabaya Branch, and the value of regression coefficient of education amounting to 0.357 and motivation regression coefficient of 0.694 . The positive value is inline with worker achievement through work motivation at $\mathrm{J}$ Trust Bank Surabaya Branch. From that case it can be concluded that education affects job performance through work motivation variable which means that the education of the workers generates a motivation to achieve the best work performance.

6. Work Experience Influence on Job Performance through Work Motivation

The influence of work experience on job performance through work motivation for $t$ count $(3.013)>$ of $t$ table $(1,682)$, thus there is a partially significant influence from work experience variable to work performance through work motivation in J Trust Bank Surabaya Branch, and regression coefficient value of education equal to 0,389 and regression coefficient of motivation equal to 0,694 . The positive value is inline with worker achievement through work motivation at J Trust Bank Surabaya Branch. From that case it can be stated that work experience is affecting job performance through work motivation variable which means work experience of the workers creates a motivation to show maturity in their work and therefore they can achieve the best work performance.

7. Work Motivation Influence on Job Performance 
The influence of work motivation on work achievement for $t$ count $(6,312)>$ from $t$ table $(1,682)$, therefore there is a partially significant influence of work motivation variable on job performance in $\mathrm{J}$ Trust Bank Surabaya Branch, and regression coefficient value of 0.694 . The positive value is inline with achievement in $\mathrm{J}$ Trust Bank Surabaya Branch. It is clear that work motivation of the workers both from themselves and the company has been able to help improving their work performance.

\section{CONCLUSION}

Education has a positive and significant impact on work motivation, it seen from the value of $t$ count (3.866) > of ttable (1.682), we can conclude that there is a partially significant influence of education variables on work motivation in $\mathrm{J}$ Trust Bank Surabaya Branch of $46,1 \%$.

Work experience has a positive and significant effect on work motivation, it is observed from $t$ count $(3,150)>$ of $t$ table $(1.682)$, it can be said that there is a partially significant influence of work experience variables on work motivation in $\mathrm{J}$ Trust Bank Surabaya Branch by $37.5 \%$.

Education has a positive and significant impact on work performance, it is acknowledged from the value of $t$ count $(2.764)>$ of $t$ tabel (1.682), therefore there is a partially significant influence of educational variables on work performance in $\mathrm{J}$ Trust Bank Surabaya Branch of $35.7 \%$.

Work experience has a positive and significant impact on work performance, showed on the value of $t$ count (3.013) > of $t$ table (1.682), therefore it is clear there is a partially significant influence of the work experience variables on job performance in J Trust Bank Surabaya Branch at 38.9\%.

Education has a positive and significant impact on job performance through work motivation, it is described on the value of education tuition (2.764) and t count motivation $(6,312)>$ of $t$ table $(1.682)$, it can be concluded that there is a partially significant influence of education variables towards work achievement through work motivation in J Trust Bank Surabaya Branch of $31.9 \%$. 
Work experience has a positive and significant impact on work performance through work motivation, it is observed from the value of work experience (3.013) and $t$ count of motivation $(6,312)>$ from $t$ table $(1.682)$, thus there is a partially significant influence of variable work experience on job performance through work motivation in J Trust Bank Surabaya Branch by $26 \%$.

Motivation of work have a positive and significant impact on work performance, it is seen from the value of $t$ count motivation $(6,312)>$ from $t$ table $(1,682)$, it can be stated that there is a partially significant influence of work motivation variable on work performance through work motivation in J Trust Bank Surabaya Branch by $69.4 \%$

\section{SUGGESTION}

J Trust Bank Surabaya Branch have to further improve the quality of its workers by doing better recruitment process. One of them is related to the prerequisite to become an employee, where in general, educational background and work experience become an important point to be considered. Background of study also must be highlighted, since at present all majors could apply and joinans bank employees, however it is better to have employees with a suitable education background which is related to the world of banking to support a better work performance.

Furthermore, in addition to improve the work performance of the employees, motivation has to be given both ways, in form of material compensation and emotional motivation. The company is also expected to create or support a conducive working environment for the employees as well as providing access and opportunities for them to advance in career levelling. That makes it open for a further research recommendation. 


\section{REFERENCES}

As'ad, Mohamad. 2001. Psikologi Industri. Yogyakarta : Liberty.

Bambang S. Soedibjo, 2005, Pengantar Metode Penelitian, STIE-STMIK Pasim, Bandung

Barid, M., Wajdi, N., Ummah, Y. C., \& Etikasari, D. (2017). UKM Development Business Loan, 1(1), 99-110.

Dwi Fitri Wijayanti (2012). Pengaruh Faktor Motivasi Terhadap Kinerja Karyawan Pada Biro Perencanaan PT Pelindo III (Persero) Surabaya

Ghozali, Imam. 2006. Aplikasi Analisis Multivariate dengan Program SPSS.

Semarang

Handoko, Hani. 2014, Manajemen Personalia dan Sumber Daya Manusia, Yogyakarta : BPFE

Hasibuan, Malayu S.P. 2008, Manajemen Sumber Daya Manusia, Jakarta : Bumi Aksara

Hamid, Sanusi. 2014, Manajemen Sumber Daya Manusia Lanjutan, Yogyakarta : Budi Utama

M. Nazir. 2003. Metode Penelitian. Jakarta : Ghalia Indonesia, cet ke-5. Hal 27

Nasution, Mulia. 2000. Manajemen Personalia, Jakarta : Djambatan

Ningtyas Prawita (2015). Pengaruh Motivasi, Pengalaman kerja, dan Disiplin Kerja

terhadap Produktivitas Kerja Karyawan PT Global Teleshop Surabaya

Novi Rizkiyani (2013). Pengaruh Relationship Marketing Terhadap Loyalitas

Nasabah Dengan Kepuasan Sebagai Variabel Intervening

Sunarto, Kamanto. 2004. Pengantar Sosiologi, Jakarta : Lembaga Penerbit FE UI

Sutisna, Perilaku Konsumen dan Komunikasi Pemasaran, (Bandung : remaja rosddakarya, 2002) Hal 145

Sutrisno, Edy. 2011. Manajemen Sumber Daya Manusia. Cetakan Ketiga. Jakarta :

Kencana Perdana Media Group

Vina Verginia Wongadi (2014). Pengaruh Masa Kerja dan Motivasi Terhadap Kinerja

Kerja Karyawan PT Asuransi Jiwa X Kantor Pemasaran Surabaya 